\title{
Is a Single Rinse Effective on Evacuating the Residual Monomers After Orthodontic Bonding? An In Vivo Study
}

\section{Braketleme Sonrası Tek Çalkalama Artık Monomerlerin Uzaklaştırılmasında Etkili Midir? Bir İn Vivo Çalışma}

\author{
(D) Erhan GÖRÜKMEZ1 , id Berza ŞEN YILMAZ2², id Sabri Illhan RAMOĞLU3
}

${ }^{1}$ Nişantaşı University, Health Vocational School, Division of Oral and Dental Health, İstanbul, Turkey

${ }^{2}$ Bezmialem Vakıf University Faculty of Dentistry, Department of Orthodontics, İstanbul, Turkey

${ }^{3}$ Altınbaş University Faculty of Dentistry, Department of Orthodontics, İstanbul, Turkey

\section{ABSTRACT}

Objective: Orthodontic adhesives are known to release potentially harmful bio-chemicals such as Bisphenol A, a derivative from Bisphenol-A-Glycidyl-Methacrylate (Bis-GMA). The aim of this study was to evaluate the amount of Bis-GMA released after the use of orthodontic adhesives polymerizing chemically or with light. We also aimed to check whether a single rinse is effective on evacuating all the residual monomers.

Methods: Light curing (Transbond XT, Unitek, CA, USA and Opal Seal Ultradent, Utah, USA) and chemically curing adhesives (Rely-a bond, Reliance Orthodontic Products, Inc., USA and Unite, 3M/ Unitek, CA, USA) were used to bond upper and lower braces of 48 patients. Patients gargled $25 \mathrm{~mL}$ drinking water for 1 minute; before bonding (T0), immediately after bonding (T1) and immediately after the first rinse (T2). The samples were placed in amber colored glass bottles, preserved in $-20^{\circ} \mathrm{C}$ and filtered through a 0.45 -micron filter and analyzed with Liquid Chromatography Tandem Mass Spectrometry.

Results: Bis-GMA release was recorded with all the adhesives. Higher amount of residual monomer was recorded for the light curing composite adhesives; Transbond XT and Opal Seal, followed by chemically curing; Unite and Rely-a bond. There was no statistically significant difference in Bis-GMA concentration at T1 and T2 ( $>0.05)$.
ÖZ

Amaç: Ortodontik adezivlerin kullanımı sonrası Bisfenol-A-GlisidilMetrakrikattan (Bis-GMA) türeyen Bisfenol A gibi potansiyel zararlı biyokimyasal ajanların ortaya çıktığı bilinmektedir. Bu çalışmanın amacı; Kimyasal ya da ışıkla sertleşen adezivlerin kullanımıyla ortaya çıkan Bis-GMA miktarının değerlendirilmesinin yanı sıra braketleme sonrası tek çalkalamanın tüm artık monomerlerin tahliyesinde etkili olup olmadığının değerlendirilmesidir.

Yöntemler: Işıkla (Transbond XT, Unitek, CA, USA and Opal Seal Ultradent, Utah, USA) ve kimyasal (Rely-a bond, Reliance Orthodontic Products, Inc., USA and Unite, 3M/Unitek, CA, USA) polimerizasyon gösteren adezivlerle 48 hastanın alt ve üst braketleri yapıştırılmıştır. Hastalar braketleme öncesi (T0), braketlemeden hemen sonra (T1) ve ilk çalkalamayı takiben (T2) 25 mL'lik içme suyunu 1 dakika boyunca çalkalamıştır. Örnekler kehribar renkli şişelerde $-20{ }^{\circ} \mathrm{C}$ 'de korunmuş ve 0,45 -mikron inceliğinde filtrelerden geçirilmiş ve likit kromatografi kütle spektrometresi ile ölçümler gerçekleştirilmiştir.

Bulgular: Tüm gruplarda braketleme sonrası Bis-GMA ortamda tespit edilmiştir. Işııla sertleşen adezivlerde daha çok miktarda olmak üzere Transbond XT, Opal Seal, Unite ve Rely-a bond gruplarında sırasıyla azalacak miktarda Bis-GMA tespit edilmiştir. T1 ve T2 ölçümleri arasında istatistiksel olarak fark yoktur ( $p>0,05)$.
Address for Correspondence: Berza ŞEN YILMAZ, Bezmialem Vakıf University Faculty of Dentistry, Department of Orthodontics, istanbul, Turkey

E-mail: berzasen@hotmail.com ORCID ID: orcid.org/0000-0002-7961-0535
Received: 22.01.2020

Accepted: 05.03.2020

Cite this article as: Görükmez E, Şen Yılmaz B, Ramoğlu Si. Is a Single Rinse Effective on Evacuating the Residual Monomers After Orthodontic Bonding? An İn Vivo Study. Bezmialem Science 2021;9(2):127-33. 
Conclusion: Significant release of Bis-GMA was observed following orthodontic bonding with either light or chemically curing adhesives. No significant difference was recorded between the first and the second rinses following bonding, meaning that a single rinse may not be effective in evacuating all the residual monomers.

Keywords: Bis-GMA, orthodontic adhesives, liquid chromatography
Sonuç: Kimyasal ve ışıkla sertleşen adeziv kullanımı sonrası ortamdaki Bis-GMA miktarı anlamlı derecede artmıştır. Braketleme sonrası ilk ve ikinci çalkalama örneklerindeki Bis-GMA miktarında anlamlı farklılık bulunmaması, tek çalkalamanın tüm artık monomerleri uzaklaştırmada etkili olamayacağı yönünde yorumlanabilir.

Anahtar Sözcükler: Bis-GMA, ortodontik adeziv, likit kromatografi

\section{Introduction}

Advancements in material science offered practitioners a variety of adhesive materials with different properties in clinical practice. Composite adhesives not only shorten treatment time but also provide easier handling.

The adhesive composites in orthodontics have similar chemical composition with dental restorative composite materials. They consist of inorganic fillers, a solvent base and an organic matrix. The organic matrix of composite materials changes into polymers with polymerization. However, some monomers not joining the polymer structure may remain (1).

The organic matrix part of composites most frequently includes glycidyl methacrylate (Bis-GMA), which decomposes into a potentially harmful bio-chemical called Bisphenol A. Bisphenol $\mathrm{A}$ is known to have undesirable effects on the reproduction capacity of rats and estrogenic activities (2,3). Its cytotoxicity and mutagenic properties have been confirmed in tissue cultures $(4,5)$.

There are different studies in the literature to measure the residual monomer quantities (6-10). However, the concentration of the Bis-GMA is depending on factors such as the temperature, the $\mathrm{pH}$, the solvent solution since it can dissolve to other components. The evacuation of the Bis-GMA from the oral medium in a short time prior to its conversion to BPA is important, however, its low concentration makes it difficult to detect in chromatography devices (11). However, there are no studies in the literature evaluating the short time release of BisGMA in vivo from different adhesives.

In the clinical practice, it is advised to ask patients to rinse their mouth with water following the bonding procedure to reduce the BPA presence to before bonding levels (12). However, there is no study in the literature evaluating the Bis-GMA concentration following orthodontic bonding cured by neither light nor chemically in vivo.

This study aims to investigate whether rinsing following bonding is effective on evacuating the residual Bis-GMA and to evaluate Bis-GMA concentration following bonding with light and chemically curing orthodontic adhesives in vivo with a sensitive method.

\section{Methods}

The study was approved by the Ethics Committee of Bezmialem Vakıf University (approval number: 71306642-050.01.04). The volunteers signed a consent form prior to participating in the study.

A power analysis was performed based on a former study (12). Accordingly, 12 patients in each of the groups would guarantee the power of $80 \%$ at the $5 \%$ confidence level allowing detection of differences.

\section{Bonding Process}

Forty-eight patients with no composite dental restoration and bonding the upper and lower jaws was possible at the same appointment were included ( $1^{\text {st }}$ molar to 1 st molar of the contralateral side). Patients with missing or extra tooth, with crowding requiring extraction, appliances containing acrylic parts such as a Nance appliance were excluded. The patients were randomly assigned into two groups $(n=24)$ using a randomization web site (https://www.randomizer.org/) based on the adhesive type; light or chemically curing. As four brands were going to be tested, the groups were subdivided using the same software. Two light curing [Transbond XT, Unitek, CA, USA $(\mathrm{n}=12)$ and Opal Seal Ultradent, Utah, USA $(\mathrm{n}=12)]$ and two chemically curing adhesives [Rely-a bond, Reliance Orthodontic Products, Inc., USA $(\mathrm{n}=12)$ and Unite, 3M/Unitek, CA, USA $(n=12)]$ were used to bond upper and lower braces. The chemical compositions of the adhesives are shown in Table 1.

The buccal surfaces of the teeth were cleaned with prophylaxis pumice and rinsed with a water-air spray. The teeth were etched with $37 \%$ orthophosphoric acid for $15 \mathrm{~s}$, rinsed and dried for 4-5 s. Every patient received the same type of braces and molar tube set (18-inch slot, Mini Master Series; Roth, American Orthodontics, Sheboygan, USA).

The composite adhesives were applied in accordance with the manufacturer's instructions and finally light-cured by using a LED curing unit (VALO LED, Ultradent, South Jordan, USA) in power mode. The primer was cured for $3 \mathrm{~s}$, the paste was cured for $3 \mathrm{~s}$ from the mesial and $3 \mathrm{~s}$ from the distal sides. For the chemically curing group, the primer was applied to both tooth and bracket surfaces, and the medium was isolated for 4 minutes following the last bracket placement.

The patients were given $25 \mathrm{~mL}$ of drinking water to rinse in a glass for 1 minute. The samples were collected at three instances: before bracket bonding (T0), immediately after bracket bonding (first rinse; T1) and immediately after the first rinse (second rinse; T2). 144 samples were collected and placed in amber colored glass flasks and stored at $-20^{\circ} \mathrm{C}$ until analysis. 
The samples were filtered through a 0.45 -micron filter. 1 $\mu \mathrm{L}$ from each sample was collected and analyzed in a liquid chromatographer (Agilent 1200, San Jose, CA, USA) and a mass spectrometer (Agilent 6460, San Jose, CA, USA). Analytical distinction was achieved by a Poroshell 120 EC-C18 3x50 mm with a particle size of 2.7 microns set at a flow speed of $0.2 \mathrm{~mL}$ per minute and column temperature of $35^{\circ} \mathrm{C}$. The gradient values are given in Table 2 .

\begin{tabular}{|c|c|c|c|}
\hline \multicolumn{4}{|c|}{ Table 1. Chemical composition of the adhesives } \\
\hline & Chemical name & (C.A.S. No.) & wt\% range) \\
\hline \multirow{5}{*}{ Transbond XT adhesive paste } & Silane treated quartz & $100402-78-6$ & $70-80$ \\
\hline & Bisphenol a diglycidyl ether dimethacrylate & $1565-94-2$ & $10-20$ \\
\hline & Bisphenol a Bis (2-hydroxyethyl ether) dimethacrylate & $24448-20-2$ & $5-10$ \\
\hline & Silane treated silica & 68611-44-9 & $<2$ \\
\hline & Diphennyliodonium hexafluorophosphate & $58109-40-3$ & $<0.02$ \\
\hline \multirow{6}{*}{ Transbond XT adhesive primer } & bisphenol a diglycidyl ether dimethacrylate & $1565-94-2$ & $45-55$ \\
\hline & triethylene glycol dimethacrylate & $109-16-0$ & $45-55$ \\
\hline & Triphenylantimony & $603-36-1$ & $<1$ \\
\hline & 4-(dimethylamino)-benzeneethanol & $50438-75-0$ & $<0.5$ \\
\hline & dl-camphorquinone & $10373-78-1$ & $<0.3$ \\
\hline & Hydroquinone & $123-31-9$ & $<0.03$ \\
\hline \multirow{4}{*}{ Opal bond adhesive } & Bisphenol a diglycidyl ether dimethacrylate & $1565-94-2$ & $<20$ \\
\hline & Ethoxylatebisphenoldimethacrylate & $41637-38-1$ & $<10$ \\
\hline & Triethylene glycol dimethacrylate & $109-16-0$ & $<5$ \\
\hline & Aluminum oxide & $1344-28-1$ & $<10$ \\
\hline \multirow{4}{*}{ Opal seal adhesive } & Bisphenol a diglycidyl ether dimethacrylate & $1565-94-2$ & $<15$ \\
\hline & Hydroxypropyl methacrylate & $27813-02-1$ & $45-55$ \\
\hline & Ethyl alcohol & $64-17-5$ & $<10$ \\
\hline & Methacrylic acid & $79-41-4$ & $<10$ \\
\hline \multirow{4}{*}{ Rely bond adhesive paste } & Bisphenol a diglycidyl ether dimethacrylate & $1565-94-2$ & $10-30$ \\
\hline & Amorphous silica & $60675-86-0$ & $50-75$ \\
\hline & Triethylene glycol dimethacrylate & $109-16-0$ & $5-10$ \\
\hline & Aluminum oxide & $1344-28-1$ & $1-5$ \\
\hline \multirow{4}{*}{ Rely bond adhesive primer } & bisphenol a diglycidyl ether dimethacrylate & $1565-94-2$ & $10-30$ \\
\hline & tetrahydrofurfuryl methacrylate & $2455-24-5$ & $30-50$ \\
\hline & 2-Hydroxyethyl methacrylate & $868-77-9$ & $10-30$ \\
\hline & Triethylene glycol dimethacrylate & $109-16-0$ & $10-30$ \\
\hline \multirow{5}{*}{ Unite adhesive paste } & Silane treated quartz & $100402-78-6$ & $50-60$ \\
\hline & Bisphenol a diglycidyl ether dimethacrylate & $1565-94-2$ & $10-20$ \\
\hline & Benzoyl peroxide & $94-36-0$ & $<2$ \\
\hline & Silane treated silica & $68611-44-9$ & $5-10$ \\
\hline & Dimethyl siloxane & $67762-90-7$ & $<2$ \\
\hline \multirow{5}{*}{ Unite adhesive primer } & bisphenol a diglycidyl ether dimethacrylate & $1565-94-2$ & $5-15$ \\
\hline & triethylene glycol dimethacrylate & $109-16-0$ & $70-80$ \\
\hline & 2,2'-(P-Tolylimino) diethanol & $3077-12-1$ & $5-15$ \\
\hline & 3- Methacryloxypropyltrimethoxysilane & $2530-85-0$ & $<5$ \\
\hline & Poly (Methyl methacrylate) (PMMA) & $9011-14-7$ & $<5$ \\
\hline
\end{tabular}

Electrospray ionization was carried out using $\mathrm{N}_{2}$ in negative and positive ion mode sets at $300{ }^{\circ} \mathrm{C}$ and a flow rate of $11 \mathrm{~mL}$ per minute, while the nebulizer was set at a pressure of 45 psi. Capillary voltage was set at 3,500 V. The retention time of the peak value for Bis-GMA was 4.81 minutes.

\section{Statistical Analysis}

The Statistical Package for the Social Sciences for Windows 22.0 (Armonk, NY: IBM Corp, 2013) was used for the 
statistical analysis. The statistical analysis was performed with Mann-Whitney $U$ test for comparing the data between two independent groups and Kruskal-Wallis test for data in two or more independent groups. Data within a group were compared using Wilcoxon signed-rank test. All tests were performed at a significance level of $\alpha=0.05$.

\section{Results}

The mean amounts of Bis-GMA detected at T0, T1 and T2, and comparison of the light and chemically curing adhesive groups are presented in Table 3. A statistically significant difference was observed between the light and chemically curing adhesive groups' samples at T1 and T2 $(\mathrm{p}=0.000)$. The light-cured group showed higher values than the chemically cured group.

Table 4 reports the results of the Mann-Whitney U test within the groups in terms of sample collection time. In all groups, the differences between $\mathrm{T} 0$ and $\mathrm{T} 1$ and between $\mathrm{T} 0$ and $\mathrm{T} 2$ were

\section{Table 2. Gradient values related to analytical division}

\begin{tabular}{|c|c|c|}
\hline Time & Function & Parameters \\
\hline 1. $\min$ & $\begin{array}{l}\text { Solvent composition } \\
\text { change }\end{array}$ & Solvent change $95 \%$ A, $5 \%$ B \\
\hline 3. $\min$ & $\begin{array}{l}\text { Solvent composition } \\
\text { change }\end{array}$ & Solvent change $2 \% \mathrm{~A}, 98 \% \mathrm{~B}$ \\
\hline 7. $\min$ & $\begin{array}{l}\text { Solvent composition } \\
\text { change }\end{array}$ & Solvent change $2 \% \mathrm{~A}, 98 \% \mathrm{~B}$ \\
\hline $7.1 \mathrm{~min}$ & $\begin{array}{l}\text { Solvent composition } \\
\text { change }\end{array}$ & Solvent change $95 \%$ A, $5 \%$ B \\
\hline
\end{tabular}

Table 3. Bis-GMA amount comparison between light and chemically curing adhesive groups

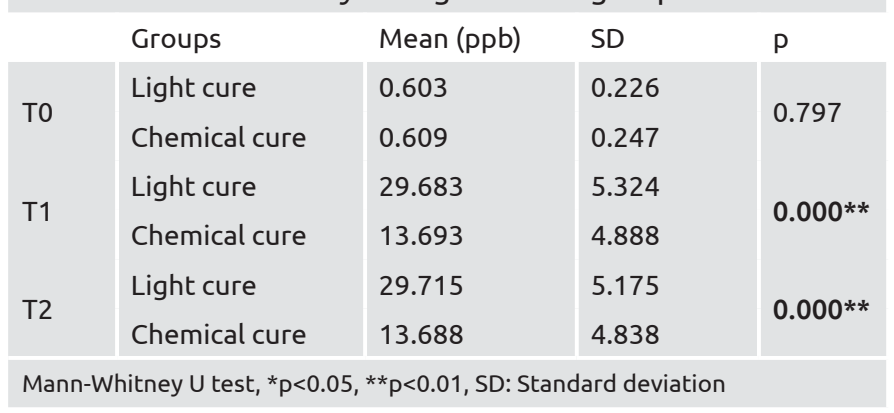

found to be statistically significant $(\mathrm{p}=0.000)$. The change between $\mathrm{T} 1$ and $\mathrm{T} 2$ was insignificant.

The mean Bis-GMA amounts recorded for the subgroups at T0, $\mathrm{T} 1$ and $\mathrm{T} 2$ and evaluation of the values for the same time period between the subgroups are given in Table 5. The differences between the means in the T0 period showed no significance ( $\mathrm{p}=0.982$ ), whereas significant differences were found for the $\mathrm{T} 1$ and T2 periods ( $\mathrm{p}=0.000)$. Mann-Whitney $\mathrm{U}$ test was used to determine which group caused the difference (Table 6). For both the T1 and T2 periods, higher Bis-GMA concentrations were recorded in the Transbond group followed by Opal and Unite. The Bis-GMA levels for the Rely-a Bond group were significantly lower than the other groups.

Table 4. Evaluation of the Bis-GMA amount within the groups according to sample collection time

\begin{tabular}{l|l|l|l|}
\hline Groups & $\mathrm{P}$ & & \\
& $\mathrm{T} 0-\mathrm{T} 1$ & $\mathrm{~T} 1-\mathrm{T} 2$ & $\mathrm{~T} 0-\mathrm{T} 2$ \\
\hline Light cure & $0.000 * *$ & 0.732 & $0.000 * *$ \\
\hline Chemical cure & $0.000 * *$ & 0.943 & $0.000 * *$ \\
\hline Mann-Whitney U test, ${ }^{*} \mathrm{p}<0.05,{ }^{* *} \mathrm{p}<0.01$ & & \\
\hline
\end{tabular}

Table 5. Evaluation of the Bis-GMA amount within the subgroups according to sample collection time

\begin{tabular}{|c|c|c|c|c|c|}
\hline & Groups & $\mathrm{N}$ & $\begin{array}{l}\text { Mean } \\
(\mathrm{ppb})\end{array}$ & SD & $\mathrm{P}$ \\
\hline \multirow{4}{*}{ T0 } & Transbond & 12 & 0.590 & 0.249 & \multirow{4}{*}{0.982} \\
\hline & Opal & 12 & 0.615 & 0.212 & \\
\hline & Unite & 12 & 0.601 & 0.252 & \\
\hline & Rely a bond & 12 & 0.616 & 0.253 & \\
\hline \multirow{4}{*}{ T1 } & Transbond & 12 & 34.892 & 0.214 & \multirow{4}{*}{$0.000 * *$} \\
\hline & Opal & 12 & 24.473 & 0.124 & \\
\hline & Unite & 12 & 18.475 & 0.204 & \\
\hline & Rely a bond & 12 & 8.910 & 0.133 & \\
\hline \multirow{4}{*}{$\mathrm{T} 2$} & Trans bond & 12 & 34.772 & 0.229 & \multirow{4}{*}{$0.000 * *$} \\
\hline & Opal & 12 & 24.657 & 0.351 & \\
\hline & Unite & 12 & 18.421 & 0.180 & \\
\hline & Rely a bond & 12 & 8.955 & 0.141 & \\
\hline
\end{tabular}

Table 6. Evaluation of the group differences at T0. T1 and T2

T0

\begin{tabular}{|l|l|l|}
\hline Groups & Opal & Unite \\
\hline Transbond & 0.982 & 0.982 \\
Opal & & 0.982 \\
\hline Unite & & \\
\hline
\end{tabular}

T1

Rely a bond
0.982
0.982
0.982

Opal
$0.00 * *$

\begin{tabular}{|l|l|} 
Unite & Rely a bond \\
\hline $0.00 * *$ & $0.00 * *$ \\
$0.00 * *$ & $0.00 * *$ \\
& $0.00 * *$
\end{tabular}

\section{$\mathrm{T} 2$ \\ 12}

Opal
$0.00 * *$

Unite
$0.00 * *$
$0.00 * *$

Rely a bond $0.00 * *$ $0.00 * *$ $0.00 * *$

Mann-Whitney U test. ${ }^{*} p<0.05 .{ }^{* *} p<0.01$ 
Table 7. Within group comparison of the samples collected at T0. T1. and T2

\begin{tabular}{|c|c|c|c|}
\hline \multirow{2}{*}{ Groups } & \multicolumn{3}{|l|}{$P$} \\
\hline & T0-T1 & $\mathrm{T} 1-\mathrm{T} 2$ & T0-T2 \\
\hline Transbond & $0.002 * *$ & 0.347 & $0.002 * *$ \\
\hline Opal & $0.002 * *$ & 0.209 & $0.002 * *$ \\
\hline Unite & $0.002 * *$ & 0.182 & $0.002 * *$ \\
\hline Rely-a Bond & $0.002 * *$ & 0.170 & $0.002 * *$ \\
\hline
\end{tabular}

The results for the intragroup comparison of the samples collected at T0, T1 and T2 are given in Table 7. The mean amount of Bis-GMA recorded at T1 and T2 for each group was found significantly higher in comparison to the T0 measurements, whereas the difference between the mean values at $\mathrm{T} 1$ and $\mathrm{T} 2$ was insignificant for all groups.

\section{Discussion}

There is a general belief that orthodontic adhesives are biologically safe, and this opinion is supported by the argument that adhesive resins are used in small quantities. However, the excess adhesive is not always completely removed prior to polymerization. Moreover, some unreacted material may remain since the composite located under the metallic components access light only by transillumination. Małkiewic et al. investigated the levels of BPA, BPA polymers and Bis-GMA resin in eluates of six commonly used orthodontic adhesives in vitro and demonstrated that most of the orthodontic adhesives released Bisphenol A or its derivatives. In the literature, it was reported that even the pellicle layer formation immediately after brushing may decrease monomer release proving that laboratory studies may not reflect precise clinical conditions (13), this is the reason why the present in vivo study was designed.

Studies analyzing residual monomers used various solvents such as distilled water, ethanol, saline, cell culture medium or artificial saliva (14). ISO recommends using distilled water to determine the chemicals that are released from resin-based materials, whereas US FDA recommends using a $75 \%$ water-ethanol solution. Accordingly, Moreira et al. (15) reported higher amounts of monomers with water-ethanol solution in comparison to using water only. In this study, drinking water presented in a glass was used as sample collection liquid since it is a routine to rinse with water following bonding.

Storage conditions are essential for specimens containing biological fluids, e.g. saliva. The saliva specimens were stored at $-80{ }^{\circ} \mathrm{C}$ or $-70{ }^{\circ} \mathrm{C}$ in the literature $(16,17)$. Kloukos et al. (12) kept from rinsing specimens at $4^{\circ} \mathrm{C}$. In this study, the specimens were placed at $-20^{\circ} \mathrm{C}$ as described by Olea et al. (18).

Liquid chromatography combined with a tandem mass spectrometer was selected in our study for investigating monomers with high molecular weight since combining the mass spectrometer with chromatographic methods is proven to provide more accurate and sensitive results compared to other chromatographic methods (19). While only liquid or gas chromatography devices can measure up to $1 \mathrm{ppm}$ (one millionth), the chromatography combined with mass spectrometry can measure up to 1 ppd (one billionth) of monomers (20), which means that the last one provides 1000 times more sensitive results.

It was shown that Bis-GMA released from composite resins hydrolyzes into Bis-HPPP after 25 hours (21). In another study, chemical and light cured composites were kept in $0.9 \%$ saline at $37{ }^{\circ} \mathrm{C}$ for 2 months. Following this period, Bis-GMA was not detected in the samples because of the fact that Bis-GMA hydrolyzes and transforms into Bis-HPP with time (22). Moreira et al. (15) found that $75 \%$ of the monomer release occurred within a few hours and $95 \%$ of the residual monomer was released within 48 hours, whereas Polydorou et al. (23) reported higher monomer release within the first 24 hours. Bis-GMA monomer levels may be affected from the water, esterase enzyme and the temperature of the oral cavity over time. Therefore, the amount of released Bis-GMA was measured in this study immediately after polymerization. Although the samples were collected at different times, similar results were obtained for both groups. This may be proving that Bis-GMA did not deteriorate under storage conditions in our study. On the other hand, in the study of Kloukos et al. (12), the amount of BPA, which is the product of Bis-GMA deterioration, was evaluated. In contradiction with our results, the authors reported that the increase in BPA concentration was reduced after the $2^{\text {nd }}$ post-bonding rinse. Since the concentration of the Bis-GMA is known to be varying with the media temperature, these differences might be related to the fact that their samples were conserved at $4{ }^{\circ} \mathrm{C}$ till the measurements were performed while our samples were stored at $-20^{\circ} \mathrm{C}$

In some studies evaluating residual monomer release from chemical or light curing adhesives, a higher degree of monomer release was reported in the chemically-cured group $(8,24)$. In the present study, higher Bis-GMA release was found in the lightcured groups, contradicting these studies. It was reported that increasing curing time leads to decreased residual monomer release (24). Depending on that, it may be hypothesized that using QTH light sources with longer exposure time would cause less residual monomer formation in comparison to highpower LED sources. This study demonstrates that reduced 
exposure time with high intensity LEDs can result in composite restorations with inferior curing depth and increased leaching of monomers.

In our study, higher Bis-GMA concentrations were recorded with light-cured composites, especially in the Transbond XT followed by the Opal Seal, Unite and Rely a Bond groups. Considering the chemical contents of these composites, monomer concentrations appeared to be similar. The composites were used in the clinic with bonding agents from their own brands. Similarly, the concentration of Bis-GMA in the bonding agent content was in harmony with the adhesives. Therefore, the presence of unreacted monomers could be expected to be higher. Furthermore, the higher Bis-GMA concentration in the Transbond XT group may be explained by the high amount of Bis-GMA (wt. 45-55\%) within the primer and the exposure of the primer to a relatively large surface.

In a study by Ratanasathien et al. (25), it was reported that Bis-GMA has a cytotoxic effect on fibroblasts when its concentration is above $4.78 \mathrm{ppm}$. On the other hand, increased estrogenic activity of HeLa cells was reported when the BisGMA concentration was above 5 ppm (26). In our study, the highest release amount of Bis-GMA was 34.8 ppd, which was considerably lower than those limits. According to these results, it may be assumed that the amount of Bis-GMA release does not reach toxic levels following orthodontic bonding.

\section{Study Limitations}

In our study, we found that light-curing composite adhesives, which are commonly used in orthodontic clinics, may be more disadvantageous in terms of biocompatibility compared to chemically curing counterparts. For this reason, manufacturers can plan studies to improve the chemical composition in order to reduce the amount of residual monomers of the light-curing composites. In addition, the use of chemically cured composite adhesives is more difficult clinically. Although fewer Bis-GMA release was found, the repositioning of incorrectly positioned brackets can cause the patients to be more exposed to additional residual monomers. Therefore, it can be suggested to use chemically curing composites with indirect bonding.

It is known that the residual monomer released in the first minutes following polymerization of adhesive resins is related to the oxygen inhibition layer, and the later release is related to residual monomers remaining in the adhesive resin matrix. One of the aims of our study was to check whether one-single rinsing was effective on evacuating the Bis-GMA immediately after orthodontic bonding. Thus, we only analyzed the prebonding, post-bonding and the second rinse samples. We proved that a single rinse was not effective in reducing the Bis-GMA concentration, but the number of effective rinsing was not presented. This might be considered as a limitation. Different rinsing solutions and the effective rinsing number may be determined with repeated rinsing procedures. Additionally, the amount of Bis-GMA can be monitored by long-term follow-up studies.

\section{Conclusion}

Bis-GMA release was observed immediately after orthodontic bonding in all groups. The highest amount of Bis-GMA was found in the Transbond group, whereas the lowest measurements were recorded in the Rely-A Bond group. The light-cured composite adhesives released higher amounts of residual monomer. The difference between the Bis-GMA levels in first and second rinses was statistically insignificant, meaning that a single rinse may not be effective in evacuating all residual monomers. However, mouth rinsing with water following orthodontic bonding may still be considered to moisten the oral mucosa and remove the possible residual acid.

\section{Ethics}

Ethics Committee Approval: Bezmialem Vakıf University (SBW_MF405-1210318105400.pdf).

Informed Consent: Obtained.

Peer-review: Externally peer reviewed.

\section{Authorship Contributions}

Surgical and Medical Practices: B.Ş.Y., Concept: E.G., B.Ş.Y., S.İ.R., Design: E.G., B.Ş.Y., S.İ.R., Data Collection or Processing: E.G., B.Ş.Y.,Analysis or Interpretation: E.G., B.Ş.Y., S.İ.R., Literature Search: E.G., B.Ş.Y., S.İ.R., Writing: E.G., B.Ş.Y., S.İ.R.

Conflict of Interest: No conflict of interest was declared by the authors.

Financial Disclosure: The authors declared that this study received no financial support.

\section{References}

1. Nunes TG, Garcia FC, Osorio R, Carvalho R, Toledano M. Polymerization efficacy of simplified adhesive systems studied by NMR and MRI techniques. Dent Mater 2006;22:963-72.

2. Darmani H, Al-Hiyasat AS. The resin monomer triethylene glycol dimethacrylate exhibits reproductive toxicity in male mice. Reprod Fertil Dev 2005;14:401-6.

3. Darmani H, Al-Hiyasat AS. The effects of BIS-GMA and TEGDMA on female mouse fertility. Dent Mater 2006;22:353-8.

4. Kleinsasser NH, Wallner BC, Harréus UA, Kleinjung T, Folwaczny $\mathrm{M}$, Hickel R, et al. Genotoxicity and cytotoxicity of dental materials in human lymphocytes as assessed by the single cell microgel electrophoresis (comet) assay. J Dent 2004;32:229-34.

5. Drozdz K, Wysokinski D, Krupa R, Wozniak K. Bisphenol A-glycidyl methacrylate induces a broad spectrum of DNA damage in human lymphocytes. Arch Toxicol 2011;85:1453-61.

6. Inoue K, Hayashi I. Residual monomer (Bis-GMA) of composite resins. J Oral Rehabil 1982;9:493-7.

7. Tarumi H, Imazato S, Ehara A, Kato S, Ebi N, Ebisu S. Postirradiation polymerization of composites containing bis-GMA and TEGDMA. Dent Mater 1999;15:238-42. 
8. Eliades T, Eliades G, Brantley WA, Johnston WM. Residual monomer leaching from chemically cured and visible light-cured orthodontic adhesives. Am J Orthod Dentofacial Orthop 1995;108:316-21.

9. Sideridou ID, Achilias DS. Elution study of unreacted Bis-GMA, TEGDMA, UDMA, and Bis-EMA from light-cured dental resins and resin composites using HPLC. J Biomed Mater Res B Appl Biomater 2005;74:617-26.

10. Tuna EB, Aktoren O, Oshida Y, Gencay K. Elution of residual monomers from dental composite materials. Eur J Paediatr Dent 2010;11:110-4.

11. Kotyk MW, Wiltshire WA. An investigation into bisphenol-A leaching from orthodontic materials. Angle Orthod 2014;84:516-20.

12. Kloukos D, Sifakakis I, Voutsa D, Doulis I, Eliades G, Katsaros C, et al. BPA qualtitative and quantitative assessment associated with orthodontic bonding in vivo. Dent Mater 2015;31:887-94.

13. Spångberg LS. Correlation of in vivo and in vitro screening tests. J Endod 1978;4:296-9.

14. Moharamzadeh K, Van Noort R, Brook IM, Scutt AM. HPLC analysis of components released from dental composites with different resin compositions using different extraction media. J Mater Sci Mater Med 2007;18:133-7.

15. Moreira Fdo C, Antoniosi Filho NR, Souza JB, Lopes LG. Sorption, solubility and residual monomers of a dental adhesive cured by different light-curing units. Braz Dent J 2010;21:432-8.

16. Major CJ, Read SE, Coates RA, Francis A, McLaughlin BJ, Millson M, et al. Comparison of saliva and blood for human immunodeficiency virus prevalence testing. J Infect Dis 1991;163:699-702.

17. Segal S, Kornienko O, Seay D, Bryce C, Huisstede L, Grangeret D. Stable trait-like individual differences in salivary uric acid (SUA):
Relations to gender and body mass index. Psychoneuroendocrinology 2015;61:69.

18. Olea N, Pulgar R, Pérez P, Olea-Serrano F, Rivas A, Novillo-Fertrell $A$, et al. Estrogenicity of resin-based composites and sealants used in dentistry. Environ Health Perspect 1996;104:298-305.

19. Pitt JJ. Principles and applications of liquid chromatography-mass spectrometry in clinical biochemistry. Clin Biochem Rev 2009;30:1934.

20. Harris DC. Quantitative chemical analysis. 8th ed. Macmillan: Clancy Marshall; 2010.

21. Jaffer F, Finer Y, Santerre JP. Interactions between resin monomers and commercial composite resins with human saliva derived esterases. Biomaterials 2002;23:1707-19.

22. Gioka C, Bourauel C, Hiskia A, Kletsas D, Eliades T, Eliades G. Lightcured or chemically cured orthodontic adhesive resins? A selection based on the degree of cure, monomer leaching, and cytotoxicity. Am J Orthod Dentofacial Orthop 2005;127:413-9.

23. Polydorou O, Hammad M, König A, Hellwig E, Kümmerer K. Release of monomers from different core build-up materials. Dent Mater 2009;25:1090-5.

24. Polydorou O, König A, Hellwig E, Kümmerer K. Long-term release of monomers from modern dental-composite materials. Eur J Oral Sci 2009;117:68-75.

25. Ratanasathien S, Wataha JC, Hanks CT, Dennison JB. Cytotoxic interactive effects of dentin bonding components on mouse fibroblasts. J Dent Res 1995;74:1602-6.

26. Tarumi H, Imazato $S$, Narimatsu $M$, Matsuo $M$, Ebisu $S$. Estrogenicity of fissure sealants and adhesive resins determined by reporter gene assay. J Dent Res 2000;79:1838-43. 